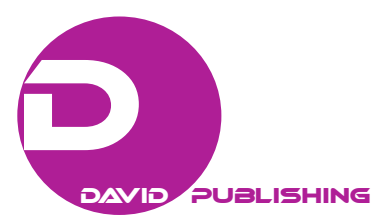

\title{
Black Gold and the Nigerian State (1956-2014): A Critical Review
}

\author{
Zara Emmanuel Kwaghe \\ Adamawa State University, Mubi, Nigeria
}

\begin{abstract}
This article discussed the oil industry in Nigeria and its impact on the economy, environment, and the citizens. The black gold (oil) was first discovered in Nigeria after several trials by white explorers in Oloibiri (present day Bayelsa State) in 1956 by Shell D'Arcy later renamed Shell-BP. By 1958, Nigeria joined the rank of oil producers, when its first oil field came on stream. It was in the same year that the first shipment of oil from Nigeria occurred. Since then oil became Nigeria's primary export with about $95 \%$ of its government revenue coming from the "black gold", pushing agriculture and other sources of revenue to the background. The study discovered that the high revenue realised from the black gold especially after the Civil War, was not used by the government to transform Nigeria from a third world to a first world country as was predicted rather heavily mismanaged. The study further discovered that the multinational companies (MNC) responsible for drilling oil in Nigeria are guilty of polluting and degrading the environment via oil spills, thereby exposing the citizens to all kinds' health related problems and further poverty. The study concludes with the following: The corruption going on in the region must be tackled head long so that the citizens (the youth especially) will begin to feel the effect of the wealth generated from black gold. The government should also invest more on the education of its citizens to enable development in the country.

Keywords: source of government revenue, multinational companies (MNC), environmental degradation, unemployment, primitive accumulation of wealth
\end{abstract}

\section{Introduction}

January 1st, 1900 marked the formal colonization of Nigeria by the British. With the hoisting of the Union Jack at Lokoja, the Colonial authorities fought and eventually conquered the various communities that formed what is now called the Federal Republic of Nigeria (Ojo, 2009). The reasons for British occupation of West Africa have been documented by many scholars such as Rodney (1972), Ake (1981), Amin (1973), and Mazuri (1980). Thus, it may not be necessary to devote much time on it. However, it suffices to reiterate that colonialism was propelled by Europe's economic and administrative needs. It was this economic need that made the colonial government give a royal charter to the Nigerian Bitumen Corporation (a German entity) and British Colonial Petroleum (a colonial charted corporation) in 1908.

Armed with the royal charter, they began to make exploratory activities for black gold (oil) around Okitipupa (Retrieved from http://www.nnpcgroup.com/NNPCBusiness/BusinessInformation/OilGasinNigeria/Industry

Zara Emmanuel Kwaghe, Ph.D., Department of History, Adamawa State University, Mubi, Nigeria.

Correspondence concerning this article should be addressed to Zara Emmanuel Kwaghe, P.M.B 25, Mubi, Adamawa State, Nigeria. E-mail: zarakwaghe@gmail.com. 
History.aspx) in western Nigeria. However, their activities were short lived due to the First World War (WWI) in 1914. The Europeans determined to discover and eventually exploit the black gold in Nigeria and continued their search after the WWI. This paper examines a brief history of the black gold and how it has affected the growth and development of the Nigerian state. The black gold accounts for about $95 \%$ of Nigeria's foreign exchange earnings, $40 \%$ or more of its GDP, and 75\% of federal government total revenue (Otiotio, 2014). For the sake of clarity, the writer will use the words "black gold" and "oil" interchangeably, since black gold refers to crude petroleum.

This study aims at achieving the following objectives:

(1) briefly discuss the history of black gold in Nigeria;

(2) examine the contributions of the oil industry to the economy of Nigeria;

(3) assess the economic and environmental impact of the industry on Nigeria;

(4) examine the role of the multinational oil companies;

(5) ascertain the level of insurgency caused by the black gold.

\section{Background}

\section{Concept of "Black Gold"}

The word "black gold" refers to underground oil also known as petroleum, considered as valuable product that makes countries and individuals rich. Petroleum is Latin word meaning "rock oil" - petra (rock) and oleum (oil). When directly translated, it means that the oil comes from underground rocks. Petroleum is a thick flammable yellow-to-black mixture of gaseous, liquid and solid hydrocarbon that occurs naturally beneath the earth's surface (Morris, 2000). In its raw form, oil consists of a black viscous fluid made up of high concentrations of organic compounds originally derived from dead animal and vegetable matter, such as plankton, which has endured extreme geological processes over millions of years. When refined into hydrocarbon fuels, chains of carbon, and hydrogen molecules, it becomes a useful fuel, because it has such a high energy density, typically 10 times that of dynamite (Duncan, 2008).

Black gold can be separated into fractions including natural gas, gasoline, naphtha, kerosene, fuel and lubricating oils, paraffin, wax, and asphalt. It is also used as raw materials for a wide variety of derivative products (Morris, 2000). Little wonder that black gold plays a central and significant role in global economies with just about every industry critically dependent on it. Black gold is a major source of energy in the world today and countries that are blessed with it have experienced economic and social transformation over the years.

Nigeria is one of the countries blessed with black gold, is Africa's largest oil producer, and has been a member of the Organization of Petroleum Exporting Countries (OPEC). Nigeria's main buyers are the United States, India, Brazil, Spain, France, and the Netherlands. Nigeria is United States' main oil supplier, according to the International Energy Agency (IEA), approximately 33\% of Nigeria's crude oil export was sent to the United States, making Nigeria its fourth largest oil supplier.

The importance of black gold to mankind cannot be downplayed. Even though, the world is advocating for an alternative source of energy, its relevance will remain for decades to come. It is used by almost all industries in the world. Most countries use it for space heating, transportation, power generation, agriculture, and many more. Due to its wide usage, countries are affected by the developments in the industry either as producers, consumers, or both. In 2008, oil provided about $34 \%$ of the world's energy needs, and in the future, oil is expected to continue to provide a leading component of the world's energy mix (Izzard, Stringer, \& Foran, 
2010). Likewise, the IEA projects that oil will provide $30 \%$ of the world's energy mix in 2030 (Priddle, 2008).

\section{Brief History of the Black Gold in Nigeria}

Nigeria is located within the sub-Sahara Africa with a land mass of $923,768.64 \mathrm{~km}^{2}$. With a population of about 160 million people, Nigeria is the largest oil producer in Africa and ranks among the first 10 in the world with oil and natural gas endowment. Nigeria's proven oil reserve in 2011 was 37.2 billion barrels, while natural gas reserve in same year was 5.292 trillion cubic meters (Retrieved from http://www.ciagov/library/publication/the-world-factbook).

Presently, nine states out of the 36 states of the federation located in the Niger Delta region produce the onshore oil and gas, while the offshore production is from wells in the Bight of Benin, Bight of Bonny, and the Gulf of Guinea (Otiotio, 2014).

As earlier mentioned, the first effort made by the colonialists to explore oil and gas in Nigeria was in 1908. This exploration activity was interrupted by the WWI. After the war, exploratory activities resumed in 1937 when Shell D'Arcy (a consortium of Shell and Royal Dutch) was awarded the sole exploratory license for the whole country (Otiotio, 2014). The exploration was carried in Owerri, but was again interrupted by the break-out of the Second World War in 1945. In 1947, activities resumed again and after several years of hard work in which 28 wells and 25 core dry holes were drilled, oil was eventually discovered in commercial quantity in Oloibiri (present day in Bayelsa State) in 1956 amidst jubilations. In the same year, Shell D’Arcy changed its name to Shell- BP Petroleum Development Company of Nigeria Limited.

The company began actual production and by 1958, its first field came on stream producing 5,100 barrels per day. In the same year, Nigeria recorded its first shipment of oil, since then Nigeria has been producing and exporting black gold. In 2011 for instance, Nigeria produced 2.53 million barrels per day (bbl/d) of crude oil (black gold) and 1trillion cubic feet (Tcf) of dry gas. Out of the 2.53 million barrels, 2.3 million barrels per day of crude oil and 17.97 million metric tons of liquefied natural gas (LNG) was exported in 2011, making Nigeria the fifth largest exporter of LNG in the world (Otiotio, 2014)

After Nigeria got her independence in 1960, exploration rights in onshore and offshore areas adjoining the Niger Delta were extended to other foreign companies such as Mobil (now Exxon-Mobil), Agip, Elf Petroleum (Total) and Gulf Oil, and Texaco (now Chevron Texaco) (Retrieved from http://www.nnpcgroup. com/NNPCBusiness/BusinessInformation/OilGasinNigeria/IndustryHistory.aspx). This act as opined by Otiotio, divested Shell of its monopoly status, though it was still the largest international oil company operating in Nigeria. These multinational companies (MNC) continued to explore the black gold after independence. In 1961, Shell's Bonny Terminal was commissioned and Texaco Overseas started operations in Nigeria. In 1962, Elf started operations in Nigeria, so was Nigeria Agip Oil Company. In 1963, Elf discovered Obagi field and Ubata gas Gulf's first production took place. In 1965, Agip found its first oil at Ebocha, while Philips Oil Company started operations in former Bendel State. In 1966, Elf started production in Rivers State with 12,000bb/d. Philips drilled its first well (Dry) at Osari-1 and discovered its first oil at Gilli-Gilli in 1967. Mobil Producing Nigeria Limited was formed in 1968 and Gulf's Terminal at Escravos was commissioned.

After the Civil War in 1970, there was a sharp rise in the world oil price and Nigeria was able to reap instant riches from its oil production (Retrieved from http://www.nnpcgroup.com/NNPCBusiness/ BusinessInformation/OilGasinNigeria/IndustryHistory.aspx). It was in the same year that Shell exceeded the one million barrel a day production mark. In 1971, Nigeria joined the OPEC. It was after joining OPEC that 
Nigeria began to take firmer control of its oil and gas resources as was done by other member countries. It was on this premise that the Nigerian National Petroleum Company (NNPC) was established in 1977. The MNC were operating under joint operating agreement (JOA) which clearly specified the respective stakes of the companies and the government of Nigeria in the ventures (Retrieved from http://www.pengassan.org/? page_id=2225). The JOA governs the manner in which revenue from the venture are allocated among the partners. However, due to some of the constraints associated with the JOA, production sharing contracts (PSC) was introduced. PSC focuses on the sharing of the output of oil and gas operations in agreed proportions between the oil company as the contractor to the government and the NNPC as representatives of government interests in the venture (Retrieved from http://www.pengassan.org/?page_id=2225).

The exploitation of oil industry is done under a joint venture agreement between the MNC and the Nigerian government. It was formerly $60 \%$ for Nigeria and $40 \%$ for the multinational corporations. But now it is $57 \%$ for Nigeria and $43 \%$ for the oil companies. The multinationals receive a share of $43 \%$ of crude oil production per day. Thus, with an oil production of 2.5 million barrels per day, the multinational corporations will receive over $\$ 18$ billion from sale of crude oil per day, while Nigeria receives about $\$ 25$ billion per day (Abubakar, 2012).

Table 1

Some Major Events in the History of the Oil and Gas Industry in Nigeria

\begin{tabular}{|c|c|}
\hline Year & Events \\
\hline 1908 & Nigerian Bitumen Co. \& British Colonial Petroleum commenced operation \\
\hline 1938 & Shell D' Arcy granted exploration rights for oil throughout Nigeria \\
\hline 1956 & First successful well drilled at Oloibiri by Shell D’ Arcy \\
\hline 1956 & Shell D'Arcy changed to Shell-BP petroleum Development Company of Nigeria Limited \\
\hline 1958 & First Shipment of oil from Nigeria \\
\hline \multirow{2}{*}{1961} & Shell's Bonny Terminal was commissioned \\
\hline & Texaco Overseas started operations in Nigeria \\
\hline \multirow{3}{*}{1962} & Elf started operations in Nigeria as Safrap \\
\hline & Nigeria Agip Oil Company started operations in Nigeria \\
\hline & Construction of the first refinery at Alesa-Eleme, PortHarcourt \\
\hline \multirow{2}{*}{1963} & Elf discovered Obagi field and Ubata gas field \\
\hline & Gulf's first production \\
\hline \multirow{3}{*}{1965} & Agip found its first oil at Ebocha \\
\hline & Philips Oil Company started operations in Bendel State \\
\hline & Commissioning of the Alesa-Eleme Refinery \\
\hline 1966 & Elf started production in Rivers State with $12,000 \mathrm{bb} / \mathrm{d}$ \\
\hline \multirow{2}{*}{1967} & Philips drilled its first well (Dry) at Osari-1 \\
\hline & Philips first oil discovery at Gilli-Gilli-1 \\
\hline \multirow{2}{*}{1968} & Mobil Producing Nigeria Limited was formed \\
\hline & Gulf's terminal at Escravo was commissioned \\
\hline \multirow{3}{*}{1970} & Mobil started production from four wells at Idaho Field \\
\hline & Agip started production \\
\hline & Department of Petroleum Resources Inspectorate commenced \\
\hline \multirow{4}{*}{1971} & Nigeria joined the Organisation of Petroleum Exporting Countries (OPEC) \\
\hline & Shell's Forcados terminal commissioned \\
\hline & Nigerian National Oil Corporation (NNOC) established by a decree \\
\hline & Mobil's terminal at Quolboe commissioned \\
\hline
\end{tabular}


Table 1 continued

\begin{tabular}{|c|c|}
\hline Year & Events \\
\hline \multirow{2}{*}{1973} & First participation agreement; Federal Government acquires $35 \%$ shares in the oil companies \\
\hline & Ashland started PSC with then NNOC (NNPC) \\
\hline \multirow{2}{*}{1974} & $\begin{array}{l}\text { Second Participation Agreement, Federal Government increases equity to 55\% } \\
\text { Elf formall changed its name from Safrap }\end{array}$ \\
\hline & Ashland's first oil discovery at Ossu-1 \\
\hline \multirow{2}{*}{1975} & First oil lifting from Brass terminal by Agip \\
\hline & DPR upgraded to Ministry of Petroleum Resources (MPR) \\
\hline \multirow{2}{*}{1976} & MPE renamed Ministry of Petroleum Resources (MPR) \\
\hline & Pan Ocean commenced production via Shell-BP's pipeline at a rate of $10,800 \mathrm{~b} / \mathrm{d}$ \\
\hline 1977 & $\begin{array}{l}\text { Government established Nigerian National Petroleum Corporation (NNPC) by Decree } 33 \text { (NNOC \&MPR } \\
\text { extinguished) }\end{array}$ \\
\hline 1978 & $\begin{array}{l}\text { Warri Refinery Commissioned with an installed refining capacity } 100,000 \mathrm{bpd} \text { and upgraded to } 125,000 \mathrm{bpd} \text { in } \\
1986\end{array}$ \\
\hline \multirow{3}{*}{1979} & Third Participation Agreement (throughout NNPC) increases equity to $60 \%$ \\
\hline & $\begin{array}{l}\text { Fourth Participation Agreement; BP's shareholding nationalised, leaving NNPC with } 80 \% \text { equity and Shell } 20 \% \\
\text { in the joint venture }\end{array}$ \\
\hline & Shell-BP changed name to Shell Petroleum Development Company of Nigeria (SPDC) \\
\hline 1980 & $\begin{array}{l}\text { Kaduna refinery commissioned with an installed capacity refining capacity of } 100,000 \text { bpd and upgraded to } \\
110,000 \text { bpd in } 1986\end{array}$ \\
\hline 1984 & Agreement consolidating NNPC/Shell joint venture \\
\hline 1986 & Signing of Memorandum of Understanding (MOU) \\
\hline 1988 & NNPC restructured into six Directorates \\
\hline \multirow{2}{*}{1989} & Fifth participation Agreement $(\mathrm{NNPC}=60 \%$, Shell $=30 \%$, Elf $=5 \%$, Agip $=5 \%)$ \\
\hline & The second Port Harcourt Refinery commissioned with 150,000 bpd \\
\hline 1990 & Ken Saro-Wiwa founded the Movement for the Survival of Ogoni People( MOSOP) \\
\hline $1990-1991$ & Jump in oil prices due to the First Gulf War \\
\hline 1991 & A private indigenous company - Consolidated Oil, recorded its first discover, Bella-1 \\
\hline \multirow{3}{*}{1993} & Production Sharing Contracts signed -SNEPCO \\
\hline & Sixth Participation Agreement $(\mathrm{NNPC}=55 \%$, Shell $=30 \%$, Elf $=10 \%$, Agip $=5 \%)$ \\
\hline & The coming on-stream of Elf's Odudu blend, offshore OML100 \\
\hline \multirow{3}{*}{1995} & SNEPCO starts drilling first Exploration well \\
\hline & NLNG's final investment decision taken \\
\hline & Ken Saro-Wiwa and five others hung and buried in an unmarked common grave \\
\hline 1999 & NLNG's first shipment of gas out of Bonny Terminal \\
\hline 2000 & NPDC/NAOC service contract signed \\
\hline 2001 & Production of Okono offshore field \\
\hline \multirow{4}{*}{2002} & New PSC's agreement signed \\
\hline & Liberalisation of the downstream oil sector \\
\hline & NNPC commences retail outlet stream \\
\hline & Nigeria estimated to have emitted more than 34.38 million tons in gas flaring \\
\hline 2005 & $\begin{array}{l}\text { The Federal High Court of Nigeria ordered that gas flaring must stop in Niger Delta community as it violates } \\
\text { guaranteed }\end{array}$ \\
\hline \multirow{2}{*}{2012} & Consideration of the Petroleum Industry Bill by the National Assembly \\
\hline & National Assembly rocked by $\$ 3$ million oil subsidy bribery scandal \\
\hline 2013 & Dutch Court ruled that Shell can be held accountable for the pollution in the Niger Delta \\
\hline
\end{tabular}

Source: Retrieved from http://www.nnpcgroup.com/NNPCBusiness/BusinessInformation/OilGasinNigeria/IndustryHistory.aspx. 


\section{Contributions of the Oil Industry to the Economy of Nigeria}

Oil industry since its first discovery in 1956, has risen from just being a merely supportive economic sector in the 1960 s to become the mainstay of contemporary Nigeria's economy. Oil is a very versatile and flexible, non-reproductive, depleting, natural resource, providing about $50 \%$ of the total energy demand in the world (Chudi-Oji, 2013). Petroleum could be used in so many ways and it is this versatility that has made oil-exporting countries of the developing world depends solely on the attendant increased revenue for their survival. Oil has contributed to increase in GDP, government revenue, foreign exchange earnings, and balance of payment and is directly linked to other sectors of the economy, such as the energy, agriculture, industry, mineral resources, and many others.

\section{Main Generator of Gross Domestic Product}

Little wonder, the Nigerian economy is largely dependent on the oil and gas sector, which accounts for about $95 \%$ of its foreign exchange earnings, $40 \%$ or more of its gross domestic product (GDP), and $75 \%$ of Federal Government revenue (Otiotio, 2014). The oil industry in Nigeria has contributed immensely to the economy and this could be seen in the rise of crude petroleum GDP, it rose from $1.6 \%$ in 1960 to $17.4 \%$ in 1970-1974 and to a peak of $24.3 \%$ in 1975-1979 periods (it was at these periods that the country was awash with money and the military government of the day could not utilise the money effectively for development).

In 1980 , it was $22 \%$, falling to $15.06 \%$ in $1985,12.90 \%$ in 1990 falling to $12.44 \%$ in 1995 (Chudi-Oji, 2013). In 2013, the GDP was worth 522.64 billion U.S dollars (Retrieved from http//www.tradingeconomics. com/Nigeria/gdp). The petroleum industry is the main generator of the GDP. The gross output consists of the proceeds from oil exports, local sales of crude oil for local refining, and sale of natural gas (Odulari, 2008). In fact, petroleum exports revenue accounts for about 70\% of total export revenue (Larsen \& Butler, 2013).

\section{Employment Opportunities}

The industry has created employment opportunities for some Nigerians. Nigerians are employed in the NNPC which represents all kinds of industry. Businessmen are involved in upstream and the downstream sector of the industry which the NNPC is involved in. Aside the above, Nigerian surveyors and civil engineers are employed to survey and map out the necessary areas for exploration, drilling locations, and construction of pits (Chudi-Oji, 2013), roads, and etc.. Young graduates have had opportunity of being employed in the oil industry, while some are entrepreneurs from marketing petroleum products. However, the percentage of unemployed youths in the oil rich Niger-Delta is as high as $25 \%$. As rightly stated by Okorie (2005), only a handful of indigenes are trained and employed by the oil companies; the rest are predominantly foreign workers. As a result, the income and profits from oil drilling do not significantly infuse the local economy. Given the historical lack of adequate economic compensation or social responsibility, by both oil companies and the federal government, the peoples of the Niger Delta have continued to marinate in poverty despite the world-coveted treasure in their own backyard.

\section{Source of Government Revenue}

Oil revenue accrued by the government as a result of the payment of substantial revenue is another significant contribution of oil industry to the economy of Nigeria. It is the responsibility of the NNPC to sell all government shares of crude oil products apart from what is processed for domestic consumption (Chudi-Oji, 
2013) and the proceeds are paid into the federal account. Aside the sale of government shares of crude oil, other sources of government revenue from oil include various taxes levied on oil companies as petroleum tax (about $85 \%$ of taxable oil income, royalties, and rents). In addition to royalties and taxes, the government also earns revenue from signature bonuses paid by the oil companies upon successful bids (Retrieved from http://www.pengassan.org/?page_id=2225).

\section{Contribution to Foreign Exchange Reserve}

Foreign exchange reserve is another area the oil industry has contributed immensely to the nation's economy. Nigeria's foreign exchange reserve has been appreciating since the discovery of oil.

\section{Development Projects}

The federal government has used the revenue accrued from oil industry to carry out different developmental projects in the country. Such projects include development of rural roads and other major roads in the country, electrification, provision of portable water, encouragement of local skills, support of higher institutions of learning (via the TETFUND and ETF), and many others.

Having discussed the contributions of the oil industry, it is pertinent to point out that the oil industry's contribution to the economy of Nigeria is largely to government revenue and foreign exchange reserve. Consider the massive increase in oil wealth, since 1970 to date, the industry cannot be said to have made a significant impact on the overall development of Nigeria. Based on the recently released GDP of Nigeria which classifies the nation's economy as the fastest growing economy in Africa, the citizens are yet to experience the economic benefits of the oil industry. As stressed by Odulari (2008), the industry's value added is helping to boost the Country's gross domestic product, but gross domestic product, is not necessarily synonymous with increased development. He further emphasized that the increase in the oil industry's value added is essentially a reflection of the significant increase in crude oil production. While Nigeria's oil revenue has continued to appreciate, and it is the fifth largest producer, about $70 \%$ of its population lives on $\$ 1$ a day, and $43 \%$ have no access to clean water. Nigeria despite being a major oil producer still imports most of its fuel and has not been able to meet the energy needs of its people. The total energy consumption for Nigeria in 2010 was 4.4 quadrillion Btu, $82 \%$ of the figure came from traditional biomass and waste, $1 \%$ from hydro power, $4 \%$ from natural gas, and $13 \%$ from oil. The electrification rate in Nigeria is $50 \%$, which means that about 80 million Nigerians have no access to electricity. The current installed capacity of the country is 6 gigawatts $(6,000 \mathrm{MW})$, though the present government has promised to install 40 gigawatts $(40,000 \mathrm{MW})$ (Otiotio, 2014).

Nigeria in spite of the increase in oil wealth is still relatively poor and underdeveloped. Why should Nigeria remain underdeveloped after over 50 years of oil production and wealth accumulation? Many scholars have accused the leaders (past and present) of wealth mismanagement and self-aggrandization, beginning with the period of oil boom - Gowon's to Jonathan Ebele good luck's regime. However, it is improper to completely blame the leaders for the underdevelopment of Nigeria, because the citizens have also helped in encouraging the leaders to continue to under develop Nigeria. The average Nigerian citizen place more emphasis on success goals and achievement rather than legitimate means and avenues in achieving success. High moral standard, integrity, honesty, and the like are no longer fashionable. Instead, corruption and corrupt practices rather than meritocracy are exalted and perpetrators are hardly punished. 


\section{Socio-economic Impact of the Black Gold}

\section{Economic Impact}

One of the main reasons why Nigeria is yet to move from developing to a developed economy is that the production of black gold in commercial quantity and the wealth it brought succeeded in making the economy a mono-economy. Nigeria is solely dependent on oil and gas neglecting the other sectors of the economy. Prior to the discovery of oil and the subsequent wealth it generated, Nigeria was heavily dependent on agricultural export. Since the early 1970s, there has been a steep drop in agricultural production correlating roughly with the rise in federal revenues from petroleum extraction (Okonta \& Douglas, 2003). Nigeria, which was once the world exporter of cocoa no longer produce cocoa for export. The same could be said of other cash crops such as groundnuts, rubber, palm produce, cotton, and many others. This decline in agriculture was not limited to only cash crops, the national output of staple food stuff also fell; this made the Shagari government to implement the import license scheme which involved Nigeria, for the first time in its history, importing basic food items.

Although, the government of President Jonathan is working hard to diversify and arrest the economic situation of the country, a lot still has to be done. The President in reeling out some of his achievements so far mentioned that the country's food import bill was reduced from 1.1 trillion Naira in 2011 to 648 billion Naira in 2012, pointing out that this has now placed Nigeria firmly on the path to food self-sufficiency (Udo, 2014). He also reported that Nigeria began exporting dried cassava chips, in 2012 which will earn the country $\$ 136$ million annually in foreign exchange. If the government should continue to invest and develop the agricultural, solid minerals, manufacturing, and other sectors of the economy with the wealth generated from oil and gas, the economy will eventually become stable and the citizens will feel the positive impact. Presently, Nigeria's economic stability is shaky and this is mainly because of the oscillating nature of the world energy market. Already OPEC has predicted decline in petroleum in six years' time (Omole, 2014). This prediction is likely based on the various researches conducted by the developed countries on the development of alternative and renewable energy that would enable the transition away from fossil fuels because of its effect on the environment (Ikeme, 2005).

Another thorny economic issue caused by the discovery of oil is that it has turned a lot of Nigerians (political office holders and non- political office holders) into pilferers and those who cannot afford are left to wallow in abject poverty. Everyone wants to have a bite of the "national cake". This has led to all forms of corrupt practices, from pilfering to outright siphoning. Looting of oil wealth by top government officials and politicians is no longer news in Nigeria. To them, oil wealth remains the largest motivation for political power (Tonwe, Ojo, \& Aghedo, 2011). In 2004, transparency international considered the late Sani Abacha of Nigeria as one of the top looters of public fund in Africa. His loot was between US\$2 billion and US\$5 billion. This has been the trend since the discovery of oil in Nigeria. As rightly put by Tonwe et al. (2011), the Nigerian oil industry is said to be the conduit through which a cabal of few individuals manipulates the economy to their own personal interest.

In one of her comments, the Minister of Petroleum Resources, Mrs. Diezani Alison-Madueke, said that Nigeria might not recover from the negative impact of crude theft and pipeline vandalism in the next 20 years or more. She further stated that the nation was producing 2.3 million barrels of crude oil per day as against its daily production of 2.567 million barrels per day in the 2013 budget. In the same vein, the Minister of Finance, Dr. Ngozi Okonjo-Iweala, lamented that the country was losing 400,000 barrels of crude oil per day because of 
crude theft, illegal bunkering, vandalism of infrastructure, and halt in production (Amaize, Oyadongha, \& Onoyume, 2013).

Oil bunkering is carried out by Nigerians of all walks of life. These criminals include oil workers, security agents hired to protect the pipelines, NNPC officials, top government officials, and anti-state militias. Bunkerers bore holes into oil pipelines and siphon oil into barges which dislodge their cargo into bigger ships waiting at sea to ship it abroad or sell it to a domestic refinery (Tonwe et al., 2011; Retrieved from https://ints1500g2.wordpress.com/2013/10/28/black-gold-black-market-nigerias-oil-curse/). The activities of bunkerers affect the daily production of oil in Nigeria. In August 2013, daily production decreased from 2.5 million barrels per day to 1.9 million barrels per day due to bunkering. This has tremendous effect on the economy of Nigeria as the country loses $\$ 7$ billion annually to oil theft (Retrieved from https://ints1500g2.wordpress.com/2013/10/28/black-gold-black-market-nigerias-oil-curse/). Aside, losing money, it also decreases OPEC's total output, thus undermining its strength. Also the money realised from oil theft help in financing political activities, insurgency, purchase of arms, and other business interests (Tonwe et al., 2011).

Commenting on how oil theft is carried out, one of the leaders of Ijaw People's Development Initiative (IPDI) Warri, Comrade Austin Ozobo explained that the oil cartel has illegal points where they siphon oil through long hoses into their waiting boats with an understanding with military officials. He further explained that the military men deployed to safe guard the area are lobbied by oil cartels to enable them load raw crude from points and to refine. Sometimes they pay between $\$ 100,000$ and $\$ 200,000$ for loading per boat and local refinery operators settle military men in their operational areas with between one and two million naira per week (Amaize et al., 2013). The question is: Who are the ones really buying the crude oil from some of the oil thieves? Where do they stock the stolen wealth? Is it in foreign bank accounts or in local banks? Who stocks the wealth there? All these are pertinent questions for the government and international friends of Nigeria to answer. Maybe their answer will help solve some of the pressing problems Nigeria is currently facing.

\section{Environmental Impact}

Niger Delta, the region where oil and gas is explored in Nigeria is made up of $70,000 \mathrm{~km}^{2}$ of wetlands formed primarily by sediment deposition. It is a home to about 20 million people and 40 different ethnic groups. It is one of the largest wetlands in the world, consisting of rivers, islands, creeks, swampy terrain, and estuaries (Chinweze, Abiola-Oloke, Onyeri, Echetub, \& Jideani, 2012). The ecology of the plain can be broken into four ecological zones: coastal barrier islands, mangrove swamp forests, fresh water swamps, and lowland rainforests. The region contains one of the highest biodiversity on earth (however, this has been distorted by constant oil spillage). The region is equally blessed with arable terrain that can sustain different variety of crops, economic trees, and different species of fresh water fish. This beautiful and rich region, since the discovery of oil in 1956, has witnessed slow poisoning of its waters gradually leading to the destruction of aquatic life, degradation of its arable land and vegetation and air pollution due to oil spill and gas flaring. Oil spillage is the pouring of petroleum products out of vessels, pipes or drilling wells to the environment thereby causing harmful effect to organic and inorganic matter in the affected areas (Chudi-Oji, 2013). Causes of oil spillage include corrosion of pipelines and tankers, sabotage/bunkering, oil production operations, and inadequate or non-functional production equipment. Corrosion occurs mainly because of long use of pipelines, while sabotage is performed 
through bunkering. Based on quantities reported by the operating companies, the NNPC estimates that approximately 2,300 cubic meters of oil are spilled in 300 separate incidents every year. Due to under-reporting, the aggregate spillage is believed to be at least 10 times higher (Okorie, 2005).

Oil spillage has a major impact on the ecosystem. It affects the ecosystem and in the process life is destroyed. It is estimated that between 1976 and 1996 a total of 4,835 incidents resulted in the spillage of about 2.5 million barrels (102.7 million U.S. gallons), of which an estimated 1.9 million barrels (79.7 million U.S. gallons; 77\%) were lost to the environment (Okorie, 2005). Records for the period show that approximately 6\%,25\% and 69\% respectively of the oil spilled in the Delta were in land, swamps, and offshore ecological beds.

The spill has led to the destruction of large tracts of the mangrove forests, mainly because the spilled oil is stored in the soil and released during rainy season. An estimated 5\%-10\% of Nigerian mangrove ecosystems have been wiped out by oil spills (Baird, 2010). In 1980 alone, spill caused by an offshore well blow out destroyed 340 hectares of mangrove. The effect of the spills further leads to the contamination of groundwater and soils. Crops and aquaculture are destroyed and when such happens it results to hunger and poverty. The numerous hydrocarbons and chemicals present in oil which affects the drinking water, represents a carcinogenic risk.

Gas flaring is another pollution that is bedeviling the Niger Delta. Gas flaring which is a practice of burning off natural gasses that are by products of oil production is poisonous to both the environment and humans. It releases a variety of potentially poisonous chemicals such as nitrogen dioxides, sulphur dioxide, and volatile organic compounds like benzene, xylene, and hydrogen sulphide, as well as carcinogens. Gas flaring by oil companies is often done close to local communities without protection for villagers who may risk nearing the heat of the flare in order to carry out their daily activities. Gas flaring has caused so much devastation in the Niger Delta that in 2005, a judgement by Federal High Court of Nigeria ordered that it should stopped (Friends of the Earth International, 2005).

\section{Role of the MNC}

The MNC operating in Nigeria operate under joint ventures with the Nigerian federal government. The joint venture manifests itself as the NNPC. Joint ventures account for approximately $95 \%$ of all crude oil output, while the local independent companies operating in marginal fields account for the remaining $5 \%$. The major six MNC operating in Nigeria are Shell Petroleum Development Company of Nigeria Limited (SPDC-British/Dutch), Chevron, Exxon-Mobil (American), Agip (Italian), Total (French), and Texaco (now merged with Chevron).

The MNC occupy a very prominent position in oil industry in Nigeria. Even though they pay royalties and taxes to the Nigerian government as correctly noted by Okorie (2005), it is still their responsibility to develop their host communities for the purpose of reparations, as well as economic and political stabilization in the interest of further development. They provide basic infrastructure, education, employment, and work with the locals (not just their community leaders) to develop new initiatives and business to replace lost farming and fishing. It is mainly because they are not caring for their host communities' that the youth have on many occasions engaged in protests against oil-related corruption and environmental concerns. Instead of finding the best way of brokering peace with the host communities, the MNCs along with Nigerian government use force to suppress the protests. Examples include the February 2005 Chevron Escravos oil terminal protest, Nigerian 
soldiers opened fire on the protesters, 1994 military killing of the Ogoni people, gruesome murder of Ken Saro-Wiwa and his kinsmen in 1995, the destruction of Odi town, and many others (Junger, 2007).

Such military involvement at the request of the all-powerful MNC has not yielded any positive results; rather it has led to the emergence of insurgents in the region, making the area unbearable for both the MNCs, government officials and other members of the communities. The protest culminated into the formation of militia that cut across the ethnic groups in the region.

\section{Insurgency in the Niger Delta}

Insurgency in the Niger Delta region of Nigeria developed mainly because of over 50 years of the marginalization of the people and their desire to be responsible for mineral wealth on their territory, the relatively poor compensation received by the communities from government-backed oil companies and the lack of opportunities for the young people of the region (Rothwell, 2011). Nigerian government has tried to deal with the insurgency in this region, because of its effect on the oil industry and the oil companies, but this has yielded little progress. One of the reasons being that violence is now the preferred means of getting silenced voices heard and also a quick source of making money.

Prior to 1995, the Niger Delta youths were not as militant as they are now. In the 1990s Ken Saro-Wiwa began the mobilisation of the Ogoni communities in protest of the degradation of the environment caused by oil spillages. The protests were characterised by non-violence, rallies, local, and international campaigns, sensitization of communities to their rights, among others. This gradual mobilisation culminated in the formation of the Movement for the Survival of Ogoni People (MOSOP) (Tonwe et al., 2011). After the death of Ken Saro-Wiwa, more movements emerged which became militant in their character and approach. Some of them include the Movement for the Emancipation of the Niger Delta (MEND), the Niger Delta People's Volunteer Force (NDPVF), the Niger Delta Vigilante Service (NDV), Movement of the Niger Delta People (MONDP), and many others. All claim to fight for the oppression of the people of the Niger Delta by the Nigerian government and the multinational oil corporations.

The militia environmentalists attack oil installations and infrastructure, kidnap oil workers, local and foreign, government officials, and demand for ransom. Their methods of activities have succeeded in shutting down a third of Nigeria's oil production leading to increase in world price of oil. Though the federal government granted amnesty to the militants, they are still operating in the region and causing more havoc to the oil industry. The militants have been able to successfully operate in the region mainly, because of their access to heavy ammunitions. The sophisticated weapons used by them have helped to sustain the struggle. These weapons were of course purchased with the oil wealth that were stolen by those that are supporting them and whom they enjoy their protection from prosecution. The question again is that who is responsible for supplying these sophisticated weapons to the insurgents? How do they receive their consignments? Is it by air, land, or by sea?

\section{Black gold and Corruption in Nigeria}

The discovery of black gold (oil) in Nigeria in 1956 marked the beginning of a new era in the economy of Nigeria. Some years after its discovery, agriculture which was Nigeria's main economic stay was gradually neglected and it eventually dwindled. Oil became Nigeria's primary export, amounting to $90 \%$ of the country's exported goods. The sudden wealth that oil brought to Nigeria after the Civil War (oil boom of the 1970s) led to the concentration of power and wealth in the hands of some few elites (leaders). These leaders who were 
supposed to use the oil wealth for the development of the country became primitive accumulators of capital. In the process of time, they legalized corruption and used different avenues to siphon wealth out of the country to foreign land. This has continued to plague Nigeria to this day. Politicians at all levels of government (federal, state, and local) in Nigeria, join politics not totally because they want to promote societal goals, but to pursue their selfish goals. Echoing the words of Akinwumi (2009), they are merely instrumental leaders who hold tenaciously to power to satisfy their private interests. That is they hardly resign from politics. Even when they are booted out, they still look for ways to remain relevant in Nigerian politics simply, because they do not want to loose the privilege of continuous accumulation of wealth.

The attitude of Nigerian leaders to the wealth generated from black gold necessitated the reaction of the Niger Delta youths to both the government and the oil companies that operate in the area. The non-remediation of polluted sites by oil companies and non-payment of compensations to the impoverished and poorly developed oil communities tend to generate open confrontations and security challenges in the region (Akpan, 2014). It is this lack of proper development in the region after 58 years of oil discovery that has brought corruption, violence, and conflicts of serious dimension on daily basis. Today, youth restiveness in the region has become a global issue that needs tackling. It deserves tackling, because their nefarious activities such as kidnapping, bunkering, killings, and many others are not only affecting the nation's economy but also the international community that patronize Nigeria's black gold.

Based on this discourse, it is no doubt that the discovery of black gold in Nigeria has impacted the nation greatly. Some writers have claimed that it is a "resource curse", because its discovery has led to the death of many, degradation of the environment, decline of agricultural exports, rise of insurgency, high level of corruption, abject poverty, and many others. In as much as the above view which is correct to a large extent, however, it is important to note that the Almighty God blessing Nigeria with oil is not a mistake. The mistake lies in the caliber of rulers that ruled Nigeria since the fall of the First Republic.

There is nothing wrong with Nigeria having oil or other natural resources. In fact, Nigeria is blessed abundantly with natural resources than any other African country. The problem of Nigeria is not the natural resources but a dearth of purpose driven leaders. Nigeria is yet to produce leaders who are ready to lay down their lives for their nation and build it. Leaders who are ready to fight corruption head long and develop the nation. Leaders like Lee Kuan Yew, who took the bull by the horns and transformed Singapore from a third world to a first world in a single generation. Singapore had no natural resources yet Lee succeeded in transforming it to an Asian Tiger economy. Today, Nigeria's economy is said to be Africa's largest economy, but of what use is it to a nation whose majority of her citizens are wallowing in abject poverty?

Nigeria at the time of independence was categorized by the international community alongside Brazil and India, as nations that will experience industrialization in no time. Today, India and Brazil have fulfilled that prophecy but Nigeria is yet to become an industrialized society. How many more years will Nigeria wait to see this prophecy fulfilled? When will the nation's avatar surface? As rightly pointed out by Maitama Sule in Akinwumi (2009); Nigeria's problem can only be solved when a good leader with sincerity of purpose, honest, dedicated, and committed; a leader who is concerned about the plight of his followers, is allowed to rule. Such a leader he further said will get the support of his followers, develop the country and establish peace, stability, and development. With development, vices like armed robbery, insurgency, and corruption will be minimized and the country will move forward. 


\section{Way Forward}

This paper has made an attempt to examine the oil industry in Nigeria and how it has affected the growth and development of Nigeria. The industry has no doubt increased the gross domestic product of the nation; however, the amount and level of corruption in government have not allowed the citizens to feel its impact. Despite the wealth flowing from oil revenues many, Nigerians still live below $\$ 1$ a day. The large scale corruption that existes among the leadership of the Niger Delta has helped sponsor the militant groups that emerged in the area who are responsible for kidnapping citizens and non-citizens and sabotaging efforts by the federal government for any infrastructural development of the area.

Nigeria and the multinational corporations that operate in the region have benefited a lot from the oil industry since its first discovery in 1956. It is therefore obligatory for both the government and the oil companies to help in developing the host communities first and the country at large so that the citizens will feel the impact of the industry.

The government has tried in different ways to address the Niger Delta issue (from Oil Mineral Producing Area Commission (OMPADEC) to Niger Delta Development Commission (NDDC), but the problem is yet to be solved. One of the major reasons why the Niger Delta problem is still lingering is the corrupt practices perpetuated by the oil companies, government officials, local chiefs, and influential individuals in the region. In order to continue drilling oil in the region without interference, the local chiefs and some few influential individuals are awarded "protection contracts and employment" by the oil companies. This "protection contracts and employment" are payoffs granted by the oil companies to protect oil-drilling operations from piracy and crude oil thievery (bunkering) by other gangs. The contracts are also used to distribute employment to a very limited pool of indigenes. They are often inequitably and corruptly distributed, and end up pitting tribe against tribe, gang against gang, and result in intra- and inter-community rivalries and violence (Okorie, 2005).

Thus, for the government to succeed in addressing the above issue, there is a need for transparency. The corruption going on in the region must be tackled head long so that the citizens (the youth especially) will begin to feel the effect of the wealth around them. Their environment must be cleaned up from oil spills to enable them to utilize the land effectively.

Education of the citizens is paramount in the development of any nation. The government should invest more on the education of its citizens to allow for high level of literacy and cognitive skills. This was one of the factors that helped the Asian Tigers achieve the Asian miracle that by 1965, all four Asian Tigers had achieved universal primary education (Page, Fischer, \& Rotemberg, 1994). This is what Nigeria is still struggling to achieve after so many decades.

Government should create stable macroeconomic environments. All tiers of government should learn to keep their budget within the limits of their monthly allocation and avoid borrowing of any kind. That way they will not destabilize the macro economy. Also, it will help check wanton spending.

Finally, there is a need for the government to intensify all efforts in revamping agriculture so that it can exist side by side with the oil sector. The oil could be likened to a beautiful woman whose beauty does not last forever. Oil is dispensable, the earlier the nation diversifies its economy, the better it is for all.

\section{Conclusions}

The article discussed the history of the black gold and its contributions to the development of Nigeria. The study discovered that the black gold has contributed immensely to the gross domestic product of Nigeria, 
helping to make the Nigerian economy the fastest growing economy in Africa. However, the corruption associated with the discovery of black gold over time has hindered the leaders from performing their duty and transforming the nation into a developed country.

\section{References}

Abubakar, A. (2012). International oil companies receive a share of 43\% of Nigeria's crude oil production per day. Retrieved from http://wwwdailytrust.com.ng/indexphp?

Ake, C. (1981). Political economy of Africa. Ibadan: Longman Group Ltd.

Akinwumi, O. (2009). The third inaugural lecture: Before we set the house ablaze: Let us consult our oracle (history). Nassarwa: State University Keffi.

Akpan, P. U. (2014). Oil exploration and security challenges in the Niger-Delta region: A case of Akwa Ibom State, Nigeria, IOSR. Journal of Research \& Method in Education, 4(2), 41-48.

Amaize, E., Oyadongha, S., \& Onoyume, J. (2013). Oil: The conspiracy that robs Nigeria billions of dollars. Retrieved from http://www.Vanguardngr.com/2013/08/oil-the-conspiracy-that-robs-nigeria-of-billions-of-dollars

Amin, S. (1973). Neo-colonialism in West Africa. London: Penguin Publishers.

Baird, J. (2010). Oil's shame in Africa Newsweek (Atlantic edition). Retrieved from www.connection.ebscohost.com

Central Intelligence Agency (US). (2013). CIA factbook. Retrieved from http://www.ciagov/library/publication/the-world-factbook

Chinweze, C., Abiola-Oloke, G., Onyeri, I., Echetub, C. K., \& Jideani, C. (2012). Oil and gas activities and the Nigerian environment. Proceedings from 32nd Annual Meeting of the International Association for Impact Assessment. Retrieved from http:// www.iaia.org

Chudi-Oji, C. (2013). Performance of economic growth in Nigeria (1970-2000) impact of oil industry. Retrieved from http://www.doublegist.com/economic-growth-nigeria-impact-oil-industry

Duncan, G. R. (2008). Blackgold. Retrieved from http://www-the guardian.com/science/2008/apr/30/energy.geology

Friends of the Earth International. (2005). Court orders oil companies to stop gas flaring in Nigeria. Retrieved from http://www.foei.org/press/court-orders-oil- Companies-to-stop-gas-flaring-in-nigeria

Pengassan. (2014). History of oil and gas industry in Nigeria. Retrieved from http://www.pengassan.org/?page_id=2225

Nigerian National Petroleum Corporation. (2014). Industry history. Retrieved from http://www.nnpcgroup.com/NNPCBusiness/BusinessInformation/OilGasinNigeria/IndustryHistory.aspx

Ikeme, J (2005). Assessing the future of Nigeria's economy: Ignored threats from global climate change debacle. Retrieved from http://www.Africa EconomicAnalysis.org

Ints1500g2. (2013) Black gold, black market: Nigeria's oil curse. Retrieved from https://ints1500g2.wordpress.com/2013/10/28/black-gold-black-market-nigerias-oil-curse/

Izzard, C., Stringer, K., \& Foran, J. (2010). Review of issues affecting the price of crude oil. Retrieved from http://www.nrcan.gc.ca

Junger, S. (2007). Oil conflict and accumulation politics in Nigeria. Retrieved from http://www.vanityfair.com/politics/features/2007/02/junger200702

Larsen, L., \& Butler, L. (2013). The governance of the global oil and gas industry: A foundation for developing a comprehensive framework. Retrieved from http://www.opecweb/en/aboutus/167htm

Mazuri, A. (1980). The African condition: A political diagnosis. Cambridge: Cambridge University Press.

Morris, W. (2000). American heritage of the English language (4th ed). NewYork: Houghton Miffilin Harcourt Company.

Odulari, G. O. (2008). Crude oil and the Nigerian economic performance. Retrieved from http://www.ogbus.ru/eng

Ojo, E. O. (2009). Mechanics of national integration in a multi-ethnic federal state. Ibadan: John Archers Publishers Limited.

Okonta, I., \& Douglas, O. (2003). Where vultures feast: Shell human rights and oil. New York: Sierra Club Books in conjunction with Crom Publishers.

Okorie, A. (2005). Nigerian oil: The role of multinational oil companies. Retrieved from http://www.web.stanford.edu/...Nigerian\%20oil\%20

Omole, S. (Producer). (2014). NTA network news [Television Broadcast]. Abuja: Nigerian Television Authority.

Otiotio, D. (2014). An overview of the oil and gas industry in Nigeria. Retrieved from http://www.academia.edu 2654835 
Page, J., Fischer, S., \& Rotemberg, J. (1994) The East Asian Miracle: Four lessons for development policy. NBER Macroeconomics Annual, 9, 211-269.

Priddle, R. (2008). World energy outlook. Retrieved from http://www.worldenergyoutlook.org

Rothwell, S. (2011). Petroviolence: Oil and Insurgency in the Niger Delta. Retrieved from http://wwwthinkafricapress.com/Nigeria/petroviolence-oil-and-insurgency-niger-delta

Tonwe, D. A., Ojo, G. U., \& Aghedo, I. (2011). Greed and grievance: The changing contours of environmentalism in Nigeria's Niger Delta region. Journal of the Historical Society of Nigeria, 20, 60-60.

Rodney, W. (1972). How Europe underdeveloped Africa. Washington, D.C.: Howard University Press.

Trading Economics. (2013). Nigeria GDP 1960-2015. Retrieved from http//www.tradingeconomics.com/Nigeria/gdp

Udo, B. (2014). Jonathan lists achievements, pledges to make Nigeria greater. Retrieved from http://wwwpremiumtimesng.com/news/152451jonathan-lists-achievements-pledges-make-nigeria greater- 2014.html 